University of Nebraska - Lincoln

DigitalCommons@University of Nebraska - Lincoln

Agronomy \& Horticulture -- Faculty Publications

Agronomy and Horticulture Department

2011

Integrating Management of Soil Nitrogen and Weeds

Samuel E. Wortman

University of Nebraska-Lincoln, swortman@unl.edu

Adam Davis

USDA-ARS

Brian J. Schutte

USDA-ARS, Schutteb@msu.edu

John L. Lindquist

University of Nebraska-Lincoln, jlindquist1@unl.edu

Follow this and additional works at: https://digitalcommons.unl.edu/agronomyfacpub

Part of the Plant Sciences Commons

Wortman, Samuel E.; Davis, Adam; Schutte, Brian J.; and Lindquist, John L., "Integrating Management of Soil Nitrogen and Weeds" (2011). Agronomy \& Horticulture -- Faculty Publications. 623.

https://digitalcommons.unl.edu/agronomyfacpub/623

This Article is brought to you for free and open access by the Agronomy and Horticulture Department at DigitalCommons@University of Nebraska - Lincoln. It has been accepted for inclusion in Agronomy \& Horticulture -Faculty Publications by an authorized administrator of DigitalCommons@University of Nebraska - Lincoln. 


\title{
Integrating Management of Soil Nitrogen and Weeds
}

\author{
Sam E. Wortman, Adam S. Davis, Brian J. Schutte, and John L. Lindquist*
}

\begin{abstract}
Knowledge of the soil nitrogen $(\mathrm{N})$ supply and the $\mathrm{N}$ mineralization potential of the soil combined with an understanding of weed-crop competition in response to soil nutrient levels may be used to optimize $\mathrm{N}$ fertilizer rates to increase the competitive advantage of crop species. A greenhouse study (2006) and field studies (2007 to 2008) in Illinois and Nebraska were conducted to quantify the growth and interference of maize and velvetleaf in response to varying synthetic $\mathrm{N}$ fertilizer rates in soils with high and low $\mathrm{N}$ mineralization potential. Natural soils were classified as having "low mineralization potential" (LMP), while soils amended with composted manure were classified as having "high mineralization potential" (HMP). Maize and velvetleaf were grown in monoculture or in mixture in both LMP and HMP soils and fertilized with zero, medium, or full locally recommended $\mathrm{N}$ rate. In the greenhouse, velvetleaf interference in maize with respect to plant biomass increased as $\mathrm{N}$ rate increased in the HMP soil, whereas increasing $\mathrm{N}$ rate in the LMP soil reduced velvetleaf interference. In contrast, velvetleaf interference in maize decreased as $\mathrm{N}$ rate increased regardless of soil class in the field experiment. With respect to grain yield, velvetleaf interference in maize was unaffected by $\mathrm{N}$ rate or soil class. In both greenhouse and field experiments, velvetleaf biomass was greater in the HMP soil class, whereas maize interference in velvetleaf was generally greater in the LMP soil class. While soil $\mathrm{N}$ levels influenced weed-crop interference in the greenhouse, the results of the field study demonstrate the difficulty of controlling soil nutrient dynamics in the field and support a maize fertilization strategy independent of weed $\mathrm{N}$ use considerations.
\end{abstract}

Nomenclature: Velvetleaf, Abutilon theophrasti Medic. ABUTH; maize, Zea mays L.

Key words: Integrated weed management, amino sugar nitrogen, crop-weed interference, Illinois soil $\mathrm{N}$ test.

Crop and weed species are adapted to high fertility and high disturbance environments (Baker 1974). However, different selection pressures have led to distinct physiological traits pertaining to nutrient acquisition and growth, which influences the competitive balance between crops and weeds (Berkowitz 1988; DiTomaso 1995). Examples of these traits include seed size, relative growth rate, rate of nutrient uptake, and biomass partitioning in response to soil nutrient supply (Bonifas et al. 2005; Dyck et al. 1995; Seibert and Pearce 1993).

Weed seeds are often one to three orders of magnitude smaller than seeds of the crops they infest, and seed size is proportional to subsequent seedling size (Seibert and Pearce 1993). Thus, weed seedlings emerge from the soil with a distinct size disadvantage. Despite this early competitive disadvantage, weed species remain competitive with crop species due in part to high rates of both growth and resource uptake. The high rate of resource acquisition by weed species is driven in part by high specific leaf area and root length (Seibert and Pearce 1993). The combination of high relative growth rate and high rate of resource acquisition increases the vulnerability of weed species to variation in external nutrient supply (Harbur and Owen 2004a, 2004b; Shipley and Keddy 1988).

Results of both greenhouse (Alkämper et al. 1979) and field experiments (Davis and Liebman 2001; Dyck et al. 1995) indicate that for certain crop-weed combinations, delaying soil $\mathrm{N}$ availability can shift the competitive balance to favor crop growth. Availability of soil $\mathrm{N}$ is dependent upon several factors including: the quantity of mineral $\mathrm{N}$ in the soil solution, soil organic carbon (SOC) content, the fraction of that SOC that is labile, and the $\mathrm{N}$ content of the soil

\footnotetext{
DOI: 10.1614/WS-D-10-00089.1

* First and fourth authors: Graduate Research Assistant and Professor, Department of Agronomy and Horticulture, University of Nebraska, Lincoln, NE 68583-0915. Second and third authors: Research Ecologists, USDA-ARS Global Change and Photosynthesis Research Unit, 1102 South Goodwin Avenue, Urbana, IL 61801. Corresponding author's E-mail: sam.wortman@huskers. unl.edu
}

substrates (Azam et al. 1993; Mary et al. 1996). Maize growth response to $\mathrm{N}$ fertilizer varies depending on the initial $\mathrm{N}$ concentration of the soil and the soil's potential for $\mathrm{N}$ mineralization, a microbial process that converts organic $\mathrm{N}$ into a mineral form readily available for plant uptake (Stanford and Smith 1972). In soils where N mineralization potential is high, additional fertilizer $\mathrm{N}$ does less to promote maize growth than in soils with low $\mathrm{N}$ mineralization potential (Mulvaney et al. 2001). Thus, if soils with high versus low $\mathrm{N}$ mineralization potential can be identified, fertilizer recommendations may be improved to reduce synthetic N fertilizer inputs (Mulvaney et al. 2006). Moreover, the differentiation of these soils may serve as a useful tool for integrating the management of soil $\mathrm{N}$ and weeds.

Velvetleaf is a problematic weed in U.S. row crop production that is less competitive than maize under reduced soil $\mathrm{N}$ levels (Barker et al. 2006a). Therefore, if soils with a low mineralization potential (LMP) or a high mineralization potential (HMP) can be correctly identified in advance of the growing season, one should be able to optimize nitrogen fertilizer recommendations and applications to enhance maize production while minimizing interference from velvetleaf. Greenhouse and field experiments were conducted with the objective of quantifying the growth and interference of maize and velvetleaf in response to varying synthetic $\mathrm{N}$ fertilizer application in local LMP and artificially created HMP soils. This objective was framed by four hypotheses: (1) maize growth and yield in monoculture are proportional to the rate of $\mathrm{N}$ addition in LMP soils, but unaffected by $\mathrm{N}$ addition in HMP soils, whereas (2) velvetleaf growth in monoculture is proportional to the rate of $\mathrm{N}$ addition in both soil classes, but is greatest in the HMP soil; (3) with respect to maize biomass and grain yield, velvetleaf interference is proportional to $\mathrm{N}$ addition in HMP soils, but will remain constant or decrease to a plateau in LMP soils, whereas (4) with respect to velvetleaf biomass, maize interference is inversely proportional to $\mathrm{N}$ addition in both LMP and HMP soils, but greatest in the LMP soils. These hypotheses are illustrated in Figure 1. 

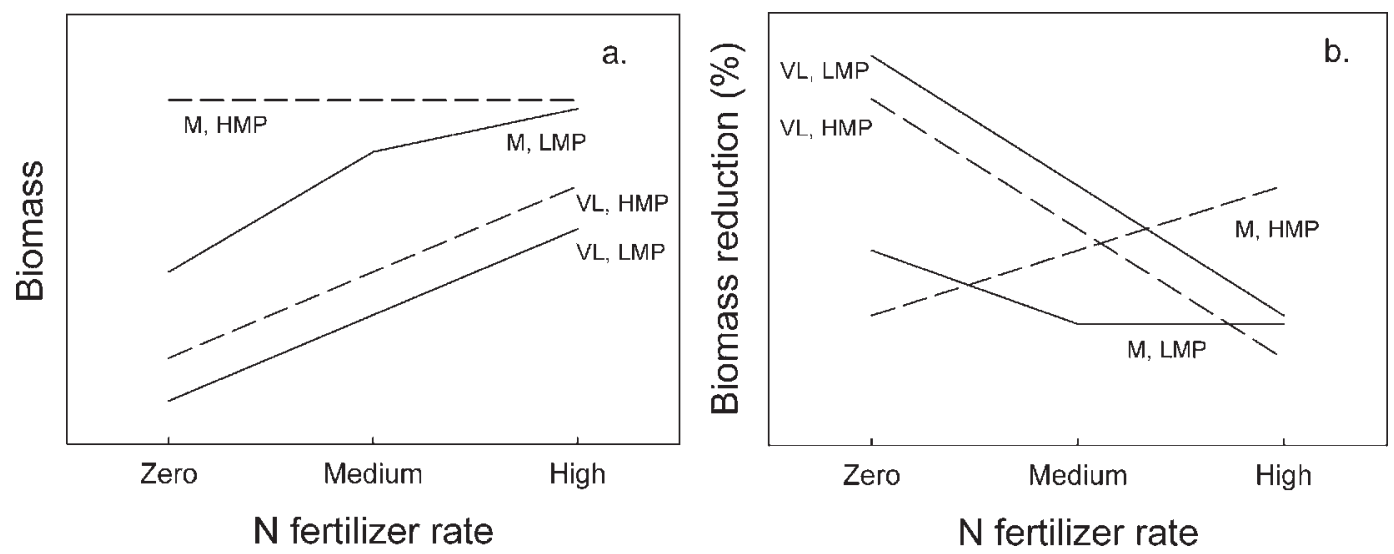

Figure 1. Hypothetical changes in maize (M) and velvetleaf (VL) biomass in monoculture (a) and growth reduction (b) in low mineralization potential (LMP) and high mineralization potential (HMP) soils as determined by soil amino sugar $\mathrm{N}$ levels.

\section{Materials and Methods}

The Illinois Soil Nitrogen Test (ISNT) for amino sugar N was utilized as the measure of soil $\mathrm{N}$ mineralization potential in this study. An amino sugar $\mathrm{N}$ level of greater than 230 parts per million (ppm) has been suggested as a critical value for soils with HMP (Mulvaney et al. 2006) and was used in the classification of soils in this study. However, we aimed to raise amino sugar $\mathrm{N}$ levels in the HMP soil class to $280 \mathrm{ppm}$ so as to improve the likelihood of establishing soils with high $\mathrm{N}$ mineralization. While the ISNT is not a perfect tool for measuring $\mathrm{N}$ mineralization potential (Barker et al. 2006b; Laboski et al. 2008; Osterhaus et al. 2008), it has been shown to be useful and is currently the best available approach to predicting mineralization potential (Klapwyk and Ketterings 2006; Lawrence et al. 2009; Williams et al. 2007). ISNT analyses were performed by university analytical laboratories. ${ }^{1}$

Greenhouse Experiment. A greenhouse study was conducted in late August and early September 2006 in Urbana, IL, to quantify the growth and interference of maize and velvetleaf in response to varying fertilizer $\mathrm{N}$ addition in local LMP and artificially created HMP soils. The experimental design was a randomized complete block with four replications and two concurrent trials starting $1 \mathrm{wk}$ apart. Temperature in the greenhouse was maintained between 20 (night, $10 \mathrm{~h}$ ) and $28 \mathrm{C}$ (day, $14 \mathrm{~h}$ ), with high intensity discharge lamps providing supplemental lighting. The experiment was blocked according to location on the greenhouse bench, and treatment design consisted of a factorial of three species combinations (maize, velvetleaf, or mixture), two soil classifications (LMP and HMP), and three $\mathrm{N}$ addition rates $\left(0,1\right.$, or $3 \mathrm{~g}$ of $\mathrm{N}$ pot $^{-1}$; equivalent to 0,20 , and $60 \mathrm{ppm} \mathrm{N}$ pot $\left.{ }^{-1}\right)$. The $\mathrm{N}$ source was urea ammonium nitrate (UAN) and was added in equal amounts to the soil surface in three intervals (planting, V3 stage of maize, and V6 stage of maize [Iowa State University Cooperative Extension Service \{ISU\} 1993]), with irrigation immediately following application.

Containers used in the experiment were $28 \mathrm{~cm}$ in diameter by $28 \mathrm{~cm}$ deep and filled with $16,000 \mathrm{~cm}^{3}$ of soil. The LMP soil class was a 50:50 mix of sand and Raub silt loam soil (Aquic Argiudoll, 28\% sand, 62\% silt, and 10\% clay) with 3.8\% total SOC. The HMP soil class included the same 50:50 mixture along with enough composted manure to achieve soil amino sugar $\mathrm{N}$ levels greater than $280 \mathrm{ppm}$ (Table 1).
Compost was combined with the soil in an electric soil mixer $7 \mathrm{~d}$ prior to planting so as to minimize initial $\mathrm{N}$ immobilization. The following equation was used to determine the amount of compost needed in each HMP experimental unit:

$$
X=Y(C-B) /(A-B)
$$

where $X$ is the amount of compost to be applied, $Y$ is the mass of soil in each HMP experimental unit, $C$ is the desired amino sugar $\mathrm{N}$ concentration (280 ppm), $B$ is the amino sugar $\mathrm{N}$ concentration of the soil determined from ISNT analysis, and $A$ is the amino sugar $\mathrm{N}$ concentration of the compost.

Plant density was held constant at two plants per container, thus maize monoculture had two maize plants, velvetleaf monoculture had two velvetleaf plants, and the mixtures had one of each species. To achieve the target densities of velvetleaf, seeds were treated in a $70 \mathrm{C}$ water bath with stir bar to stimulate germination (Holm and Miller 1972), planted at high densities, and subsequently thinned. All plants were watered on a daily basis and supplemented with a weekly micronutrient solution (Bonifas et al. 2005).

Maize and velvetleaf plants were harvested at the V8 growth stage of maize and shoot biomass obtained by drying tissues at $60 \mathrm{C}$ to constant mass. Interference of maize and velvetleaf was quantified by calculating biomass reduction (BR) as:

$$
B R=\left(B_{\text {mono }}-B_{\text {mix }}\right) / B_{\text {mono }}
$$

where $B_{\text {mono }}$ is biomass plant ${ }^{-1}$ grown in monoculture and $B_{\text {mix }}$ is biomass plant ${ }^{-1}$ grown in mixture.

Field Experiment. A field experiment was conducted in 2007 and 2008 in Illinois and Nebraska. The 2007 Illinois site was located at the University of Illinois Crop Sciences Research and Education Center in Urbana, IL. The soil type is a Raub silt loam (Aquic Argiudoll, 28\% sand, 62\% silt, and 10\% clay) with $3.8 \%$ SOC. The 2008 Illinois site moved to the Central Illinois Irrigated Growers Association (CIIGA) Research Farm, in Havana, IL, to take advantage of the strongly nutrient-limited soils at this location. The predominant soil type at the CIIGA farm is a Plainfield sand (Typic Udipsamment, $94 \%$ sand, $4 \%$ silt, and $2 \%$ clay) with $0.7 \%$ SOC. The Nebraska site was located at the University of Nebraska Agricultural Research and Development Center (ARDC) near Mead, NE, in both years. The predominant soil type at the ARDC is a Sharpsburg silty clay loam (fine, 


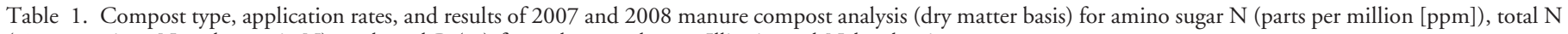
(\% ammonium $\mathrm{N}$ and organic $\mathrm{N})$, and total $\mathrm{P}(\%)$ from the greenhouse, Illinois, and Nebraska sites.

\begin{tabular}{|c|c|c|c|c|c|c|}
\hline & Type & Amino sugar $\mathrm{N}$ & Total N & Total P & $\mathrm{C}: \mathrm{N}$ & Compost rate \\
\hline & & ppm & 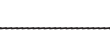 & - & ratio & $\mathrm{mg} \mathrm{ha}^{-1}$ \\
\hline Greenhouse & Municipal leaf & 492 & 0.63 & 0.24 & 28.2 & 95.4 \\
\hline \multicolumn{7}{|l|}{ Illinois } \\
\hline 2007 & Beef composted & 500 & 0.97 & 0.14 & 23.7 & 26.1 \\
\hline 2008 & Beef composted & 508 & 1.33 & 0.25 & 16.7 & 29.7 \\
\hline \multicolumn{7}{|l|}{ Nebraska } \\
\hline 2007 & Beef composted & - & 0.41 & 0.58 & - & 40.7 \\
\hline 2008 & Beef composted & - & 0.51 & 0.53 & - & 32.5 \\
\hline
\end{tabular}

smectitic, mesic typic Argiudoll) with 3.3\% SOC. The previous crop across sites and years was maize (except sorghum was the previous crop at the Nebraska site in 2008). The Illinois sites and the 2008 Nebraska site were nonirrigated, but the 2007 Nebraska site was irrigated.

The experimental design at both locations was a split-split plot randomized complete block. The treatments were a factorial design consisting of two soil classifications (main plot: LMP or HMP), three species combinations (subplot: maize, velvetleaf, or mixture), three fertilizer $\mathrm{N}$ addition rates (sub-subplot: $0,0.5 \times$, or $1 \times$ local $\mathrm{N}$ recommendation using a broadcast application of UAN at planting), and four replications for a total of 72 experimental units. Main plots (soil classification) were 3.1 by $36.6 \mathrm{~m}$ with maize planted in rows spaced $0.76 \mathrm{~m}$ apart. Subplots (species combinations) were 3.1 by $9.2 \mathrm{~m}$, and sub-subplots ( $\mathrm{N}$ rates) were 3.1 by $3.1 \mathrm{~m}$.

Soil classification was established 3 wk prior to planting by taking a composite sample of 10 (Nebraska) to 30 (Illinois) soil cores $(2.5 \mathrm{~cm}$ diameter by $20 \mathrm{~cm}$ deep) in each replicate block and submitting them for analysis using the ISNT for amino sugar N. Samples from replicates with low levels of amino sugar $\mathrm{N}$ (less than the median of all replicate samples) were classified as LMP soils, and the remaining replicates were classified as HMP soils and amended with compost to raise the amino sugar $\mathrm{N}$ level of the soil to $280 \mathrm{ppm}$. At the Illinois site, the compost was analyzed for amino sugar $\mathrm{N}$ and Equation 1 was used to calculate the amount (on a mass:mass basis) of compost required to achieve 280 ppm amino sugar $\mathrm{N}$ in the HMP soil class. At the Nebraska site, the compost was analyzed for total $\mathrm{N}$ (ammonium $\mathrm{N}$ and organic $\mathrm{N}$ ), and University of Nebraska-Lincoln fertilizer recommendations were used to determine compost addition rates (based on available soil $\mathrm{N}$ and yield goals) (Shapiro et al. 2008). Compost analysis and application rates are provided in Table 1. Compost was applied with a manure spreader and incorporated to a depth of $8 \mathrm{~cm}$ with a field disk (Nebraska) or to a depth of $20 \mathrm{~cm}$ with a soil finisher (Illinois). Compost was applied to HMP soils between 7 and $14 \mathrm{~d}$ prior to planting so as to minimize initial $\mathrm{N}$ immobilization. Three soil cores $(2.5 \mathrm{~cm}$ diameter by $20 \mathrm{~cm}$ deep) per soil class in each replicate were collected after compost and synthetic $\mathrm{N}$ application but prior to planting to confirm soil classification.

Maize (Pioneer "33Y45" in Illinois and Dekalb "6166RR" in Nebraska) was planted at a target population of 72,000 plants ha ${ }^{-1}$ throughout the entire experimental area on April 20, 2007, and April, 30, 2008, in Nebraska and on May 8, 2007, and May 7, 2008, in Illinois. Maize was planted with a six-row planter so as to include one border row on each side of the four-row sub-subplot experimental units. Maize plants growing in the velvetleaf monoculture plots were carefully removed with a hoe or by hand at the V2 to V4 stage of growth. Velvetleaf was broadcast by hand on the same day as maize to achieve a density of 30 plants per meter row in both monoculture and mixture and subsequently thinned to a final density of 10 plants per meter row (equivalent to 130,000 plants $\mathrm{ha}^{-1}$ ) when plants reached the two full leaf stage. Velvetleaf plants included in the final population were growing within $15 \mathrm{~cm}$ (either side) of the maize row; all velvetleaf plants outside of this range were removed. Grass weeds in the study were managed with a PRE application of pendimethalin (Illinois) or encapsulated alachlor (Nebraska), and broadleaf weeds (besides velvetleaf) were removed with a hoe.

Maize and velvetleaf vegetative biomass samples were harvested at the V10 (Illinois) or VT (Nebraska) stage of maize growth in both years. Vegetative biomass was determined by harvesting three (Nebraska 2007), four (Nebraska 2008), or five (Illinois 2007 and 2008) randomly selected plants from the first and fourth rows of each experimental unit, drying tissues at $60 \mathrm{C}$ to constant mass and weighing. Biomass was analyzed on a per unit area basis by dividing the number of sampled plants by the total plant population within an experimental unit to determine biomass $(\mathrm{kg})$ on a per hectare basis. Maize grain yield was harvested in 2008 at the Illinois site and in both years at the Nebraska site. Maize ears were harvested by hand from the entire length of the two interior rows of each experimental unit; thus, the total harvest area was 3.1 by $1.5 \mathrm{~m}$. Grain was shelled from maize ears with a stationary sheller, and yields were adjusted to $0.155 \mathrm{~g} \mathrm{~kg}^{-1}$ water content. Similar to the greenhouse study, interference according to biomass and grain yield reduction were calculated with Equation 2, except that $B_{\text {mono }}$ is biomass $\left(\mathrm{kg} \mathrm{ha}^{-1}\right)$ or grain yield $\left(\mathrm{kg} \mathrm{ha}^{-1}\right)$ per unit area grown in monoculture, and $B_{\text {mix }}$ is biomass or grain yield per unit area grown in mixture.

Statistical Analysis. Values from both greenhouse and field trials for maize and velvetleaf vegetative biomass, BR, and maize grain yield and yield loss along with soil amino sugar $\mathrm{N}$ values from all experiments were analyzed using the Mixed procedure in SAS. ${ }^{2}$ Effects were tested across years but within sites because of differences in sampling times at each site. Fixed effects included soil class, $\mathrm{N}$ rate, year (or trial in the greenhouse experiment), and their interactions, and the random effect was block (block by trial in the greenhouse experiment). Differences among treatment means were 

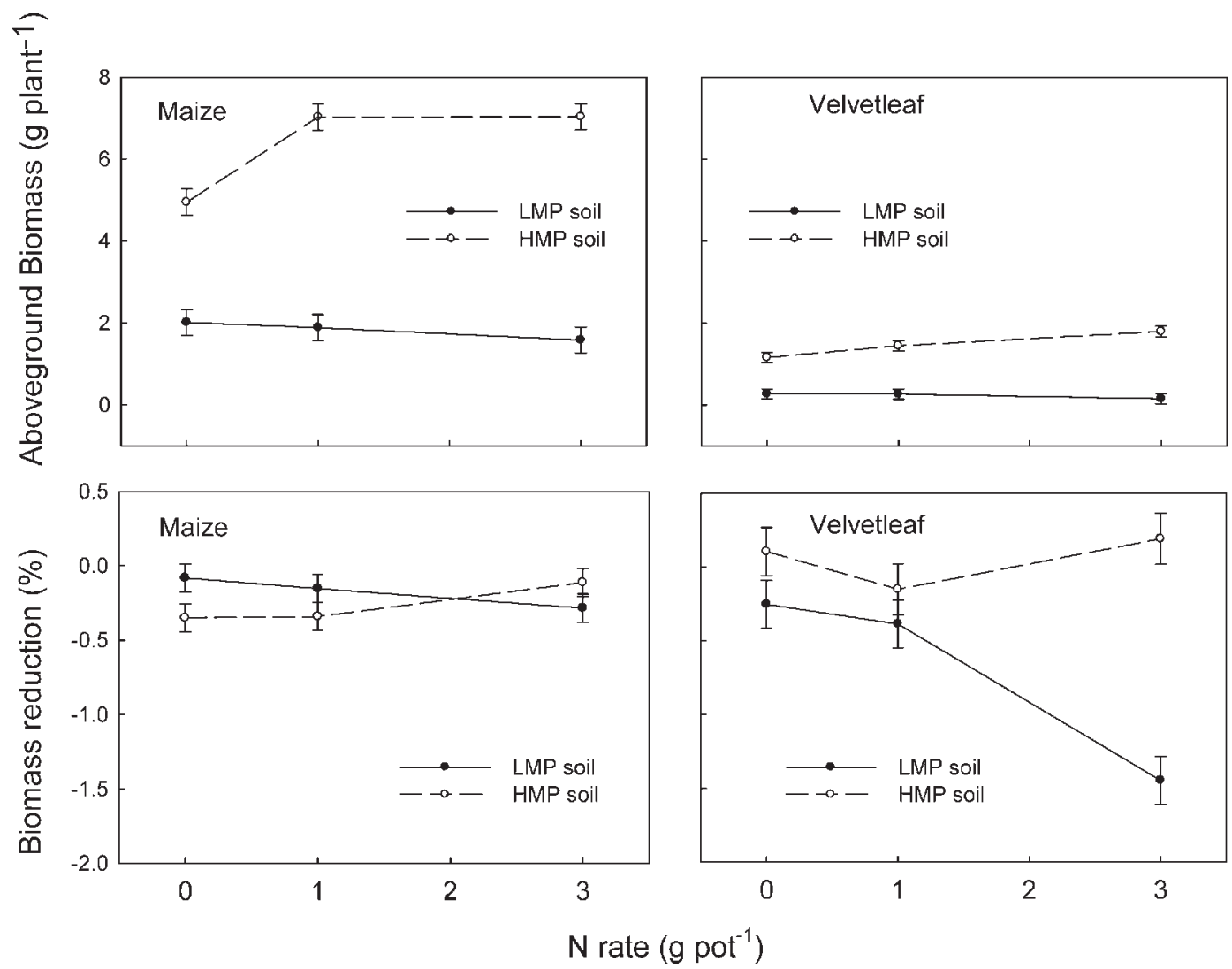

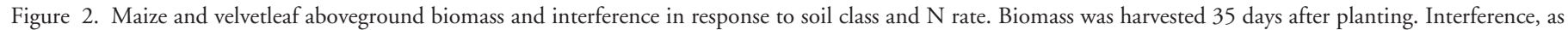

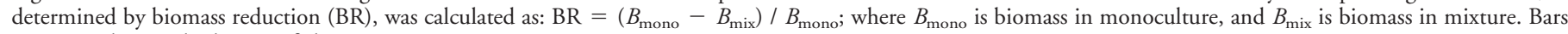
represent the standard error of the mean.

compared using the standard error of the least squares means estimate with a significance level of 0.05 .

\section{Results and Discussion}

Greenhouse Experiment. Maize vegetative biomass in monoculture was influenced by the interaction of soil class and $\mathrm{N}$ rate $(P<0.01$; Figure 2$)$. Maize biomass increased as $\mathrm{N}$ rate increased from $0 \mathrm{~g} \mathrm{pot}^{-1}$ to $1 \mathrm{~g} \mathrm{pot}^{-1}$ in the HMP soil, but was not influenced by $\mathrm{N}$ fertilizer rate in the LMP soil. This is contrary to hypothesis 1 , in which we expected maize biomass to increase with $\mathrm{N}$ rate in the LMP soil but be unaffected by $\mathrm{N}$ rate in the HMP soil.

Monoculture grown velvetleaf biomass was affected by the interaction of soil class and $\mathrm{N}$ rate $(P=0.01)$ (Figure 2). We hypothesized that velvetleaf biomass would increase with $\mathrm{N}$ rate regardless of soil class. However, velvetleaf biomass did not change in the LMP soil class. There are at least two possible explanations for the lack of maize and velvetleaf response in the LMP soil class. It is possible that the high $\mathrm{N}$ rate $\left(3 \mathrm{~g} \mathrm{pot}^{-1}\right)$ resulted in overfertilization and the excessive nitrogen salts "burned" the plant tissue in the LMP soil but not the HMP soil because the greater organic carbon inputs (composted manure) in the HMP soil may have immobilized some of the excess $\mathrm{N}$, preventing salt damage (Burger and Jackson 2003). These results may also be attributed to the high sand content of the potting soil, which may have caused excessive drainage and $\mathrm{N}$ leaching in the LMP soils (Lord and Mitchell 1998).
Overall, biomass of maize and velvetleaf (data not shown) were greater in mixture compared to monoculture (BR is negative), indicating that intraspecific interference was greater than interspecific interference for both species (Spitters 1983). Intraspecific competition was most pronounced in the LMP soil class. Increasing the $\mathrm{N}$ rate in the LMP soil class was most beneficial to the velvetleaf grown in mixture, as maize interference in velvetleaf decreased with increasing $\mathrm{N}$ rate (Figure 2). These results are congruent with previous studies that have demonstrated the reduced competitive ability of weed species at low soil $\mathrm{N}$ levels (Blackshaw et al. 2003; Bonifas et al. 2005; Dyck et al. 1995; Menalled et al. 2004; Rasmussen 2002). In maize, velvetleaf interference tended to decrease in response to increasing $\mathrm{N}$ rate in the LMP soil, but the effect was not significant $(P=0.11$; Figure 2$)$. These results indicated that, for mixtures of velvetleaf and corn with respect to monocultures, velvetleaf growth was promoted to a greater degree than maize growth by high rates of $\mathrm{N}$ fertilization in the LMP soil class, suggesting a competitive advantage for velvetleaf in this soil environment. This is consistent with the results of Barker et al. (2006a) who found that velvetleaf was more competitive than maize at high rates of $\mathrm{N}$ fertilization.

These results offer strong support for hypothesis 3 and limited support for hypothesis 4. We hypothesized that velvetleaf interference in maize would increase as $\mathrm{N}$ rate increased in the HMP soil class and would be inversely proportional to $\mathrm{N}$ rate in the LMP soil. While differences among $\mathrm{N}$ rates within a soil class were not significant, there 


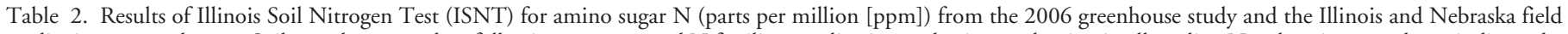

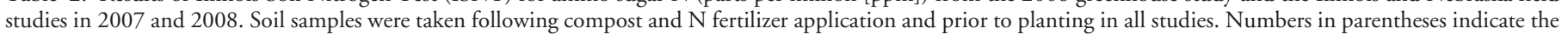
standard error within a particular year and soil class.

\begin{tabular}{|c|c|c|c|c|c|c|}
\hline & \multicolumn{2}{|c|}{ Greenhouse } & \multicolumn{2}{|c|}{ Illinois } & \multicolumn{2}{|c|}{ Nebraska } \\
\hline & $\mathrm{LMP}^{\mathrm{a}}$ & HMP & LMP & HMP & LMP & HMP \\
\hline \multicolumn{7}{|c|}{ Amino sugar $\mathrm{N}$} \\
\hline 2006 & $110(1.1)$ & $265(3.5)$ & & & & \\
\hline 2007 & & & $223(5.0)$ & $264(3.9)$ & $248(6.5)$ & $255(5.0)$ \\
\hline 2008 & & & $92(3.3)$ & $109(7.3)$ & $256(2.7)$ & $264(4.1)$ \\
\hline
\end{tabular}

a Abbreviations: LMP, low mineralization potential soil; HMP, high mineralization potential soil.

was an interaction effect of soil class and $\mathrm{N}$ rate on maize growth reduction $(P=0.03)$. This interaction is evident in Figure 2, where velvetleaf interference in maize generally increased with $\mathrm{N}$ rate in the HMP soil and decreased in the LMP soil. It was this interaction of soil class and $\mathrm{N}$ rate that prompted field studies in 2007 and 2008 to further test these hypotheses. Similarly, we hypothesized that maize interference in velvetleaf would be inversely proportional to $\mathrm{N}$ rate in both soil classes, but this was evident only in the LMP soil.

Field Experiment. Despite compost amendments to artificially create the HMP soil class, soil amino sugar $\mathrm{N}$ in the top $20 \mathrm{~cm}$ of soil did not differ among soil classes at the Nebraska site (Table 2). Moreover, soils at the Nebraska site were all greater than the critical value of $230 \mathrm{ppm}$ amino sugar $\mathrm{N}$ established by Mulvaney et al. (2006), suggesting that these soils may have behaved like HMP soils regardless of compost amendment. The amino sugar $\mathrm{N}$ levels were greater in the HMP soil compared to the LMP soil at the Illinois sites in 2007 and 2008. Despite these differences, we were not able to raise amino sugar $\mathrm{N}$ levels in the HMP soils to the desired level of 280 ppm in either year or site. Regardless of compost amendment, the 2008 Illinois amino sugar $\mathrm{N}$ values were much lower than the critical value of $230 \mathrm{ppm}$ established by Mulvaney et al. (2006), suggesting that these soils may have behaved like true LMP soils. Despite substantial compost additions at both sites $\left(>26 \mathrm{Mg} \mathrm{ha}^{-1}\right)$, it proved difficult to raise field soil amino sugar $\mathrm{N}$ concentrations high enough to create distinguishable soil classes based on $\mathrm{N}$ mineralization potential. Although we set out to establish LMP and HMP soils according to a critical value of $230 \mathrm{ppm}$ amino sugar $\mathrm{N}$, what we actually achieved were compost-amended (HMP) and nonamended (LMP) soil classifications.

Maize vegetative biomass in monoculture increased with increasing $\mathrm{N}$ rate in both soil classes at Illinois $(P<0.01)$ and was affected by an interaction of soil class by year $(P<0.01$; Figure 3). The interaction of soil class by year was due to a lack of maize biomass response in the HMP soil at the medium $\mathrm{N}$ rate in 2008, while in 2007 maize biomass was consistently greatest in the HMP soil at all $\mathrm{N}$ rates. At the Nebraska site, vegetative biomass of maize also increased with $\mathrm{N}$ rate regardless of soil class $(P<0.01)$ and differed between years $(P<0.01)$. Because amino sugar $\mathrm{N}$ levels in both soil classes were well above the critical value for HMP soils established by Mulvaney et al. (2006), we expected to see nitrogen saturation in the HMP soil (e.g., no effect of increasing $\mathrm{N}$ rate on maize biomass due to high $\mathrm{N}$ mineralization potential of soil). However, we observed increases in maize biomass with increasing $\mathrm{N}$ rate, suggesting that the amino sugar $\mathrm{N}$ threshold for determining the $\mathrm{N}$ mineralization potential of a soil may need to be set substantially higher than the $230 \mathrm{ppm}$ proposed by Mulvaney et al. (2006). Moreover, the increase in maize biomass with $\mathrm{N}$ rate regardless of soil class did not support our hypothesis 1.

Velvetleaf vegetative biomass in monoculture at Illinois was influenced by both an interaction between $\mathrm{N}$ rate and soil class $(P=0.04)$ and an interaction between year and $\mathrm{N}$ rate $(P=0.02$; Figure 4$)$. The soil class by $\mathrm{N}$ rate interaction was the result of high levels of biomass in the HMP soil at the zero $\mathrm{N}$ rate in 2007 and at the high $\mathrm{N}$ rate in 2008. Velvetleaf biomass did not respond consistently to $\mathrm{N}$ addition in either soil class in 2007, but increased with $\mathrm{N}$ rate regardless of soil class in 2008, as hypothesized. We did not expect to observe an interaction of soil class and $\mathrm{N}$ rate on velvetleaf biomass, but overall biomass was generally greater in the HMP soil class, which offers some support for hypothesis 2. Velvetleaf biomass grown in monoculture was a function of $\mathrm{N}$ rate $(P<0.01)$ but not soil class at Nebraska (Figure 4). Because the natural amino sugar $\mathrm{N}$ content of the Nebraska soils was greater than $230 \mathrm{ppm}$, we would expect the increase in velvetleaf biomass with $\mathrm{N}$ rate to be similar among soil classes at Nebraska.

Velvetleaf interference in maize with respect to plant biomass at Illinois was influenced by the interaction of soil class and year $(P<0.01$; Figure 5$)$. The interaction effect was the result of greater velvetleaf interference in maize in the HMP compared to the LMP soil in 2007, but the opposite trend in 2008. At the Nebraska site, there were no differences in velvetleaf interference in maize except at the $0 \mathrm{~N}$ rate in 2007, where velvetleaf interference in maize was greater in the LMP than the HMP soil. We expected that velvetleaf interference in maize would be greater in the HMP soil class and increase steadily with $\mathrm{N}$ rate, but this was not observed. For both soil classes, increasing $\mathrm{N}$ rate generally reduced velvetleaf interference in maize. This result is inconsistent with the observations in our greenhouse study (Figure 2). At both the Illinois and Nebraska sites, maize interference in velvetleaf differed with soil class $(P=0.04)$ but not $\mathrm{N}$ addition (Figure 6). As predicted by a component of hypothesis 4 (Figure 1b), maize interference in velvetleaf was reduced more in the LMP soil compared to the HMP soil class. In contrast to another prediction of hypothesis 4, however, maize interference in velvetleaf was either unaffected by or increased with $\mathrm{N}$ rate in both soil classes.

Maize grain yield increased with $\mathrm{N}$ rate $(P<0.01)$ at the Illinois site in 2008, but was unaffected by soil class or the interaction between soil class and $\mathrm{N}$ rate (Figure 7). In Nebraska, maize grain yield was influenced by the interaction of $\mathrm{N}$ rate and year $(P<0.01)$, but not affected by soil class 


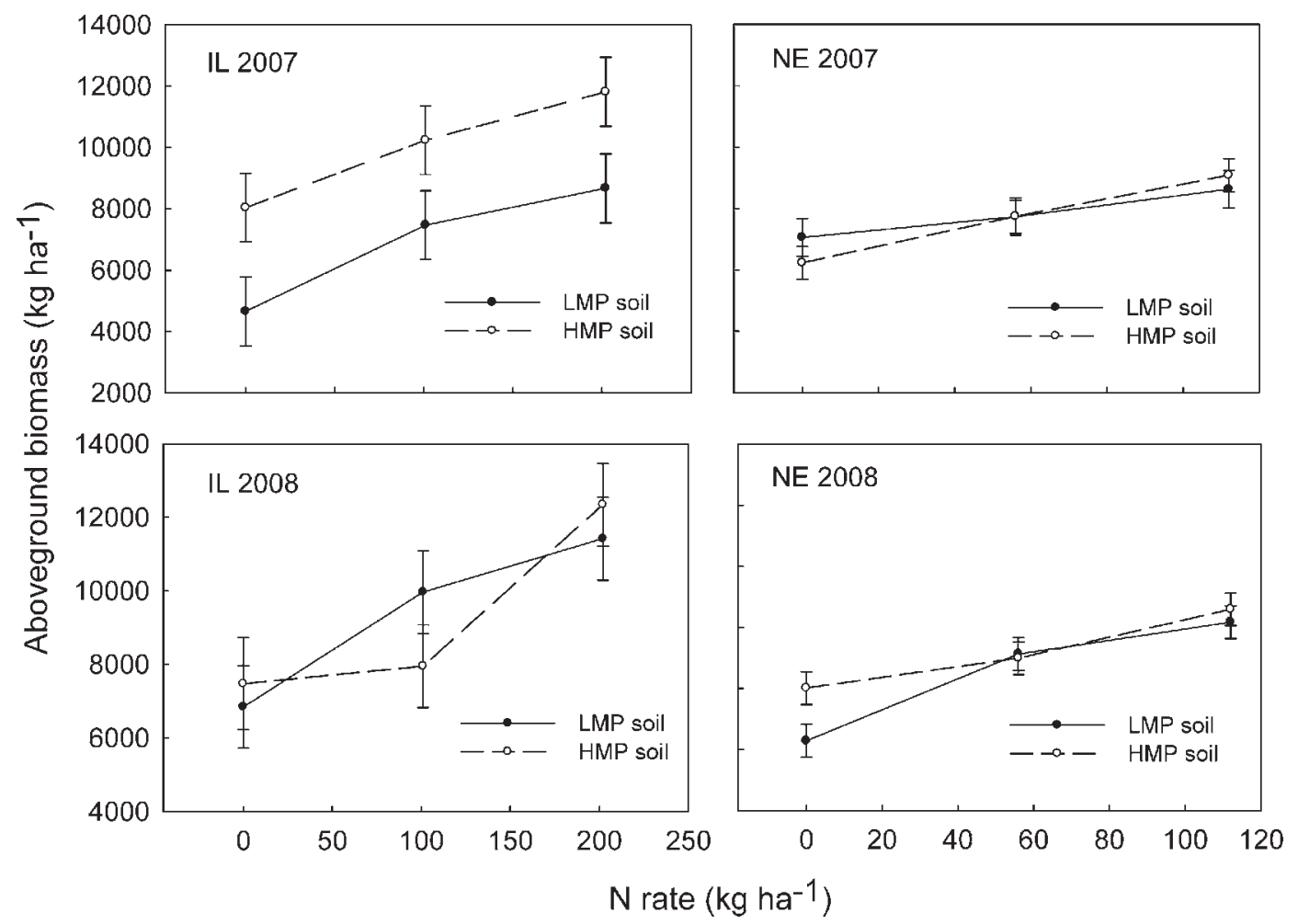

Figure 3. Maize aboveground biomass in monoculture in response to soil class and N rate in Illinois and Nebraska in 2007 and 2008 . Biomass was harvested at the V10 stage of maize growth in Illinois and the VT stage in Nebraska. Bars represent the standard error of the mean.

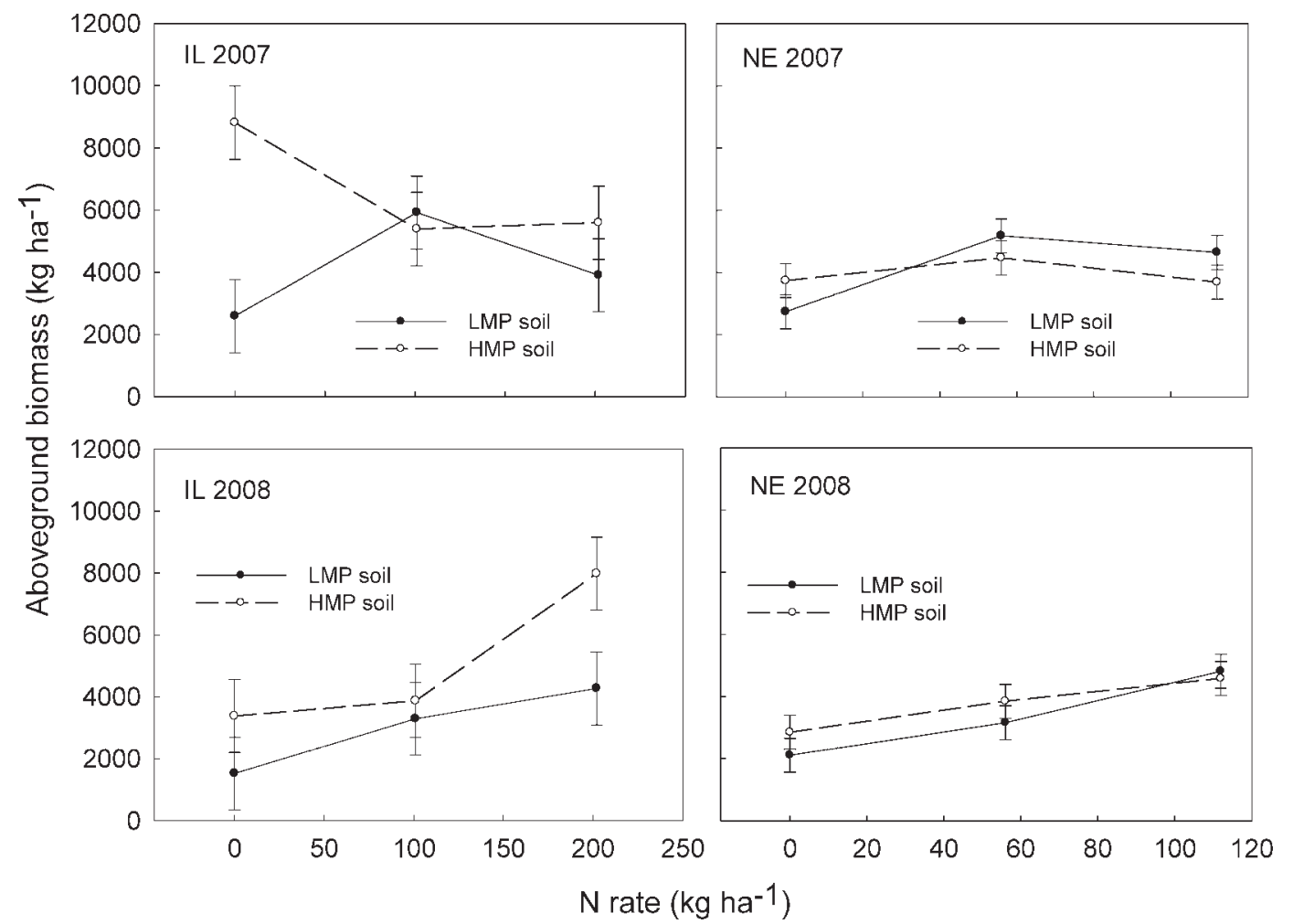

Figure 4. Velvetleaf aboveground biomass in monoculture in response to soil class and N rate in Illinois and Nebraska in 2007 and 2008. Biomass was harvested at the V10 stage of maize growth in Illinois and the VT stage in Nebraska. Bars represent the standard error of the mean.

Wortman et al.: Soil $\mathrm{N}$ and weed management 167 


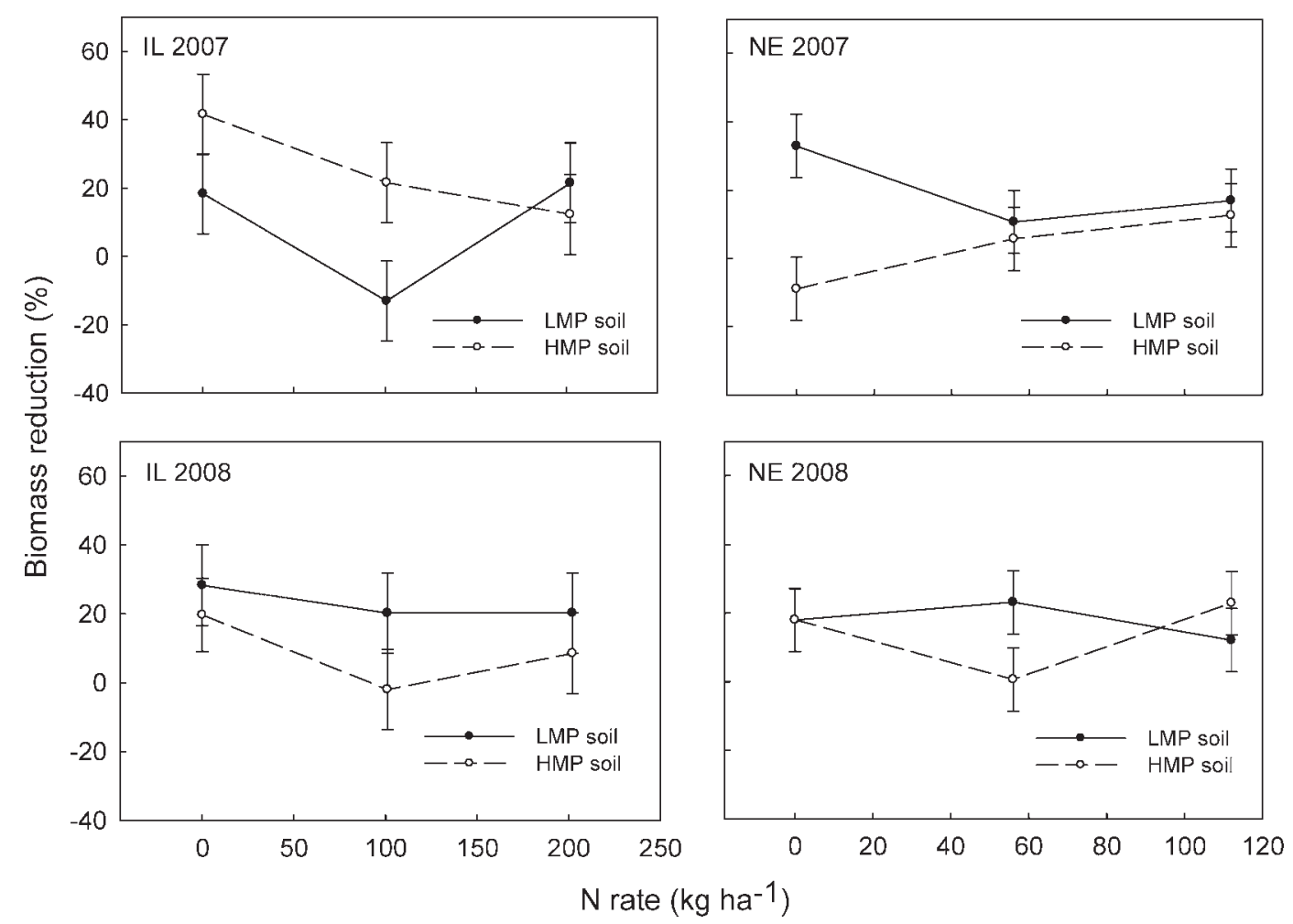

Figure 5. Effect of soil class and $\mathrm{N}$ rate on velvetleaf interference in maize (maize biomass reduction [BR]). Biomass was harvested at the V10 stage of maize growth in Illinois and the VT stage in Nebraska. $\mathrm{BR}=\left(B_{\text {mono }}-B_{\text {mix }}\right) / B_{\text {mono; }}$ where $B_{\text {mono }}$ is biomass in monoculture, and $B_{\text {mix }}$ is biomass in mixture. Bars represent the standard error of the mean.

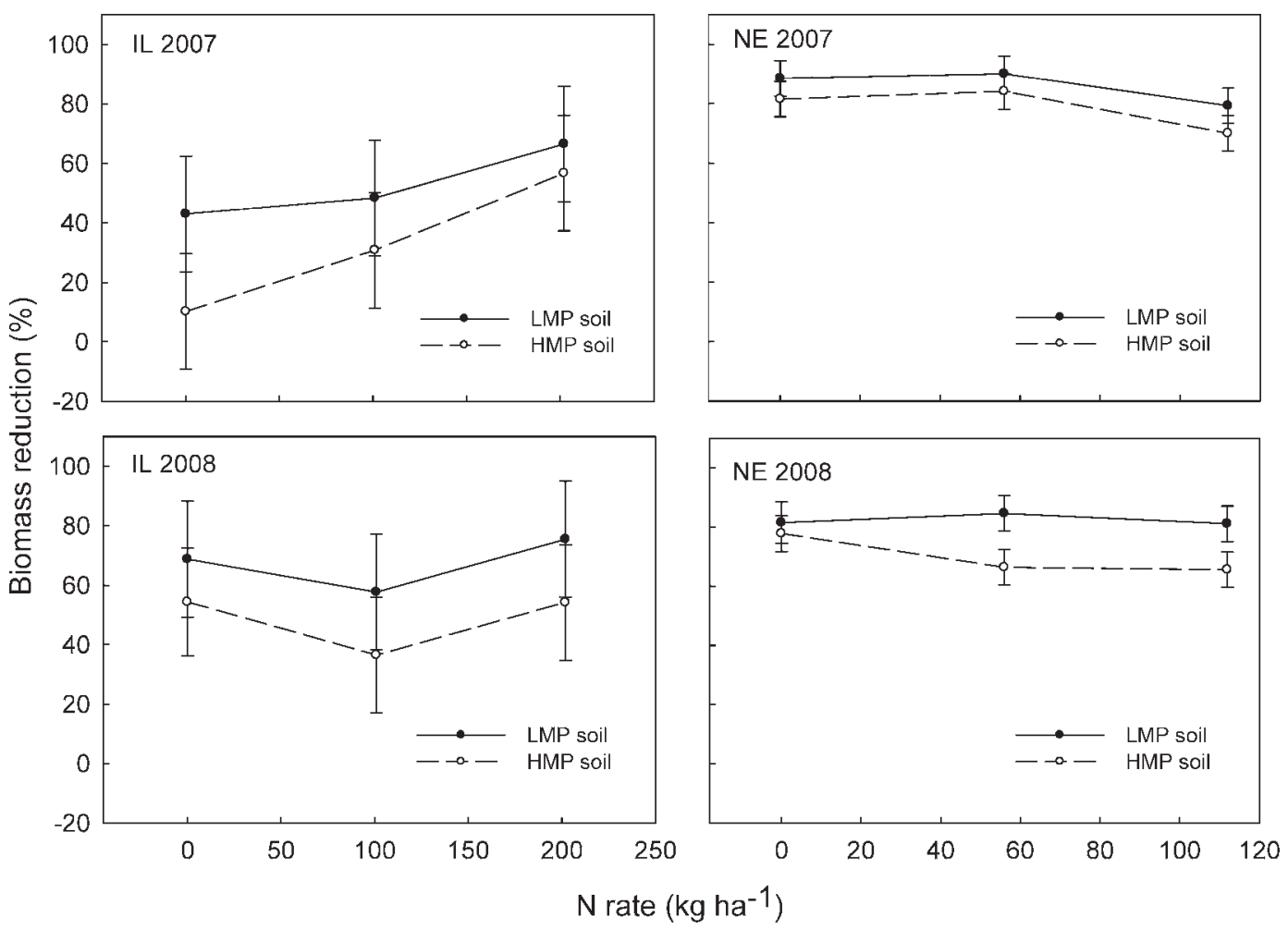

Figure 6. Effect of soil class and $\mathrm{N}$ rate on maize interference in velvetleaf (velvetleaf biomass reduction [BR]). Biomass was harvested at the V10 stage of maize growth in Illinois and the VT stage in Nebraska. Biomass reduction was calculated as: $\mathrm{BR}=\left(B_{\mathrm{mono}}-B_{\mathrm{mix}}\right) / B_{\text {mono}}$; where $B_{\text {mono }}$ is biomass in monoculture, and $B_{\text {mix }}$ is biomass in mixture. Bars represent the standard error of the mean. 

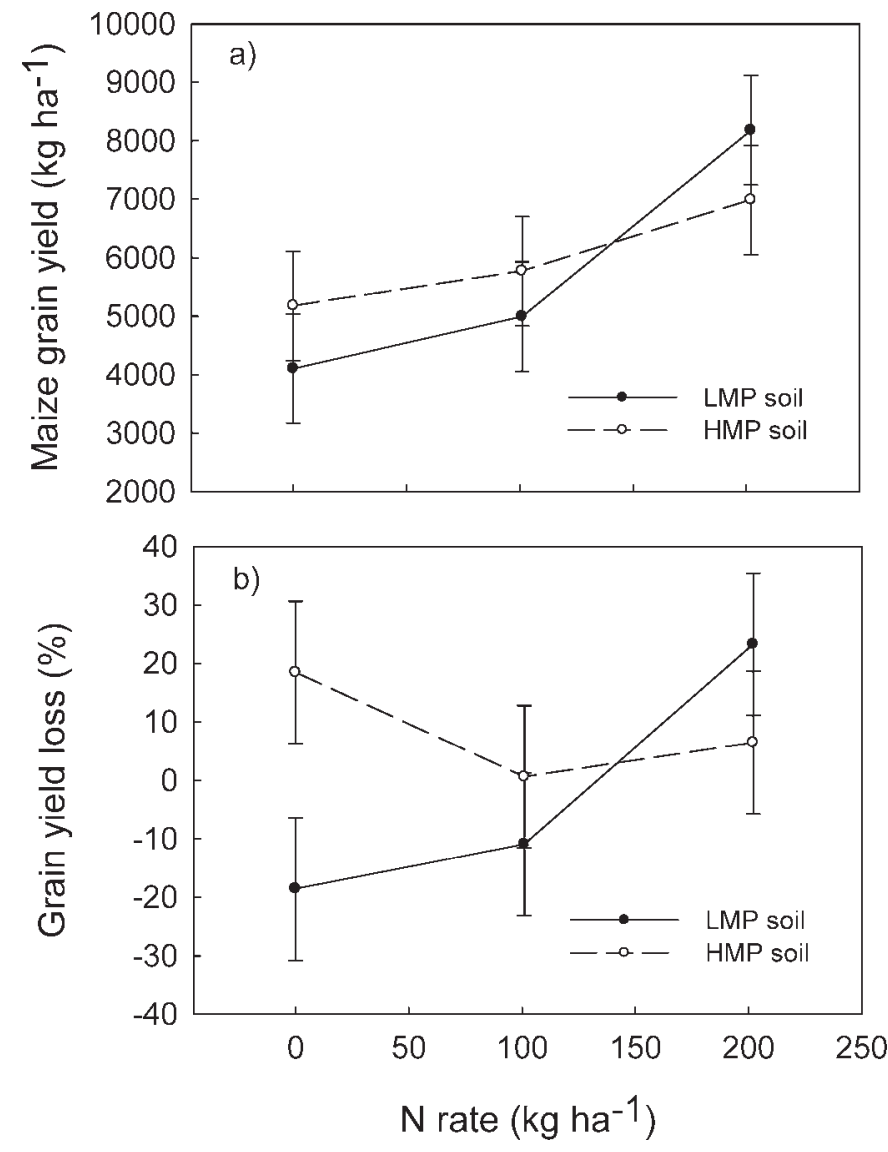

Figure 7. Maize grain yield and yield loss in response to soil class and $\mathrm{N}$ rate in Illinois in 2008. Yield loss $(\mathrm{YL})$ was calculated as: $\mathrm{YL}=\left(Y_{\text {mono }}-Y_{\text {mix }}\right) / Y_{\text {mono; }}$; where $Y_{\text {mono }}$ is maize yield in monoculture, and $Y_{\text {mix }}$ is maize yield when grown in mixture with velvetleaf. Bars represent the standard error of the mean.
(Figure 8). Grain yield in monoculture was unaffected (or decreased slightly) by $\mathrm{N}$ rate in 2007 , but increased with increasing $\mathrm{N}$ rate in 2008 . The lack of yield response to $\mathrm{N}$ fertilizer in 2007 may have resulted from high nitrate levels in the irrigation water. The Nebraska site was moved to an adjacent field without irrigation in 2008 to alleviate this issue.

Implications for Management and Future Directions. Despite the overall responsiveness of weed-free maize yield to increasing $\mathrm{N}$ rate, velvetleaf interference in maize was unaffected by $\mathrm{N}$ rate, soil class, or the interaction of these two factors at either site (Figures 7 and 8). The results from our field studies provide no support for a fertilization strategy for maize intended to give the crop a competitive edge over weeds under different background levels of mineralizable soil $\mathrm{N}$. Rather, these results support an $\mathrm{N}$ fertilization strategy based on the economic optimum inorganic $\mathrm{N}$ fertilizer application level for cost-effective maize yield production, independent of weed $\mathrm{N}$ use considerations. These results are consistent with those of Barker et al. (2006a), who found that corn yield loss due to velvetleaf interference was similar across $\mathrm{N}$ fertilizer rates.

It is worthwhile noting that previous demonstrations of integrated soil fertility and weed management strategies took place in either of two settings: shallow, low-fertility soils with coarse textures and very low soil organic matter levels (Davis and Liebman 2001; Dyck et al. 1995) or controlled environment studies in either water or sand culture (Alkämper et al. 1979; Bonifas et al. 2005; Harbur and Owen 2004a; Shipley and Keddy 1988). In both of these settings, N fertilizer additions result in reliable shifts in inorganic $\mathrm{N}$ concentrations within the growth medium. The deep soils of the U.S. Midwest may confound attempts at optimal N management for minimizing weed-crop interference due to
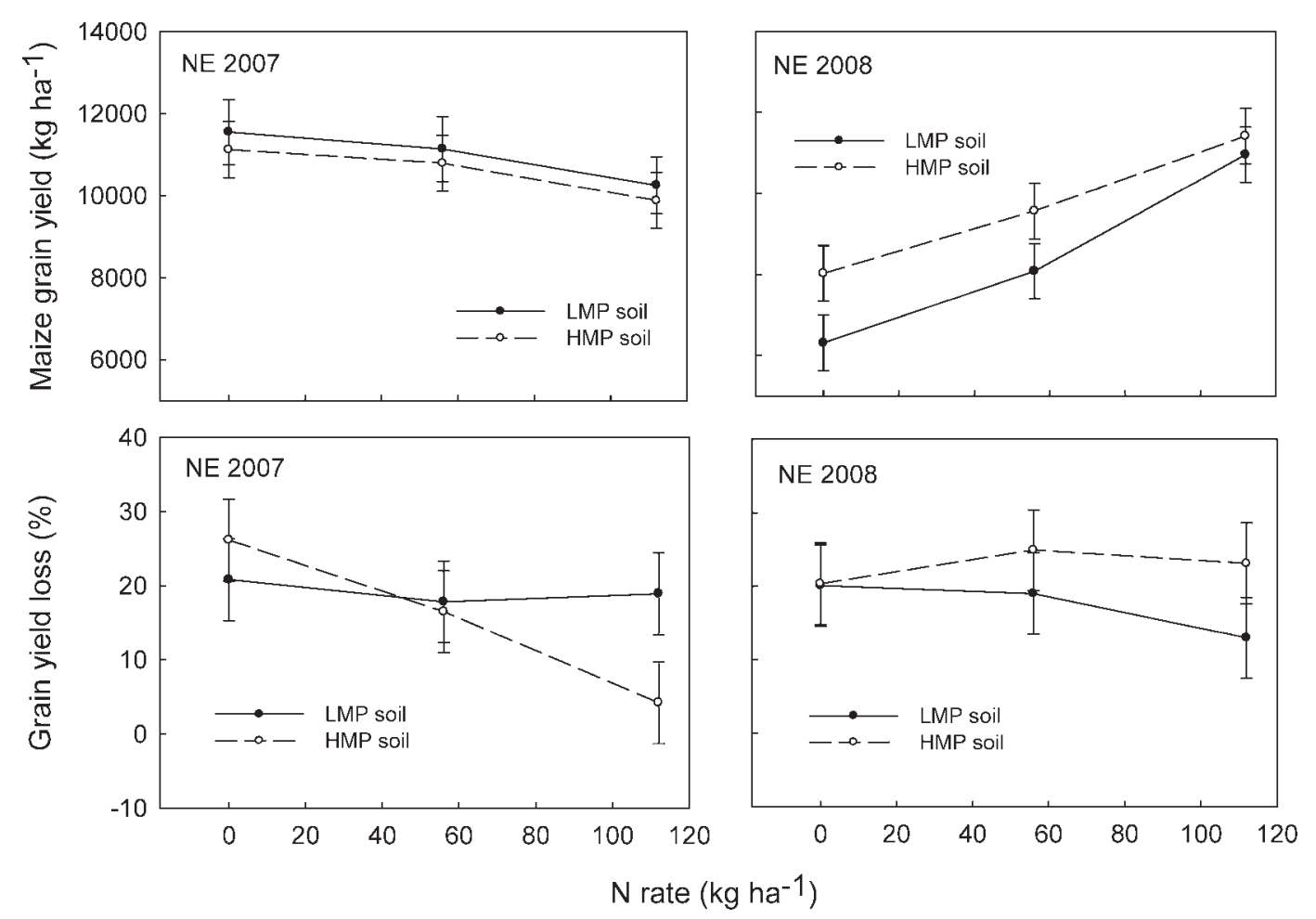

Figure 8. Maize grain yield and yield loss in response to soil class and $\mathrm{N}$ rate in Nebraska in 2007 and 2008. Yield loss $(\mathrm{YL})$ was calculated as: $\mathrm{YL}=\left(Y_{\text {mono }}-Y_{\text {mix }}\right) /$ $Y_{\text {mono; }}$ where $Y_{\text {mono }}$ is maize yield in monoculture, and $Y_{\text {mix }}$ is maize yield in mixture with velvetleaf. Bars represent the standard error of the mean. 
the HMP of these soils. Moreover, the soil sampling depth of $20 \mathrm{~cm}$ utilized in this study likely does not provide an accurate assesssment of $\mathrm{N}$ quantities available to maize plants, which can access soil $\mathrm{N}$ at depths of up to $1.2 \mathrm{~m}$ (Shapiro et al. 2008). Thus, future research on the integrated management of soil nitrogen and weeds should either focus on early season maize growth and weed interference or utilize deeper soil sampling to obtain more accurate estimates of available and mineralizable soil $\mathrm{N}$ for the entire growing season.

Although the interaction of soil class and $\mathrm{N}$ rate in this study was a predictor of velvetleaf interference in maize in the greenhouse, the results were not replicated in the field. This demonstrates the complexity of the plant-soil system and the weed-crop interactions occurring within this context. Moreover, the interaction of soil class and $\mathrm{N}$ rate in the greenhouse resulted in significant but relatively small differences in BR. BR due to plant interference was less than $2 \%$ in the greenhouse, but was often greater than $40 \%$ in the field with standard errors of $+/-10 \%$. Thus, the variation that often accompanies field data made it difficult to detect the subtle interactions observed in the greenhouse. However, the relatively high variation observed for grain yield loss in this study is congruent with the variation reported within particular site-years of previous weedcrop interference studies (Lindquist et al. 1996, 1999).

Finally, the difficulty of artificially creating the HMP soil class with compost amendments in the field hindered our ability to accurately test the effects of soils classified by $\mathrm{N}$ mineralization potential on weed-crop competition. Future weed-crop competition studies may be more successful if existing LMP and HMP soils are identified and used to test these hypotheses. This would likely require on-farm experimentation, but may be necessary given the demonstrated difficulty of artificially creating two distinguishable soil classes in the field.

\section{Sources of Materials}

\footnotetext{
${ }^{1}{ }^{15} \mathrm{~N}$ Analysis Service at the University of Illinois, 1102 South Goodwin Avenue, Urbana, IL 61801.

${ }^{2}$ SAS Institute Inc., 100 SAS Campus Drive, Cary, NC 275132414.
}

\section{Acknowledgment}

The authors would like to thank Erin Haramoto and Darren Binder for their technical assistance.

\section{Literature Cited}

Alkämper, J., E. Pessips, and D. V. Long. 1979. Einfluss der Düngung auf die Entwickelung und Nahrstoffnahme verschiedener Unkräuter in Mais. European Weed Research Society Symposium, Mainz, Germany. Paris: European Weed Research Society.

Azam, F., F. W. Simmons, and R. L. Mulvaney. 1993. Mineralization of N from plant residues and its interaction with native soil N. Soil Biol. and Biochem. 25:1787-1792.

Baker, H. G. 1974. The evolution of weeds. Ann. Rev. Ecol. Syst. 5:1-24.

Barker, D. C., S. Z. Knezevic, A. R. Martin, D. T. Walters, and J. L. Lindquist. 2006a. Effect of nitrogen addition on the comparative productivity of corn and velvetleaf (Abutilon theophrasti). Weed Sci. 54:354-363.

Barker, D. W., J. E. Sawyer, M. M. Al-Kaisi, and J. P. Lundvall. $2006 \mathrm{~b}$. Assessment of the amino sugar-nitrogen test on Iowa soils: II. Field correlation and calibration. Agron. J. 98:1352-1358.

Berkowitz, A. R. 1988. Competition for resources in weed crop mixtures. 1st ed. Pages 89-119 in M. A. Altieri and M. Liebman, eds. Weed Management in Agroecosystems: Ecological Approaches. Boca Raton, FL: CRC Press.
Blackshaw, R. E., G. Semach, and H. H. Janzen. 2003. Fertilizer application method affects nitrogen uptake in weeds and wheat. Weed Sci. 50:634-641.

Bonifas, K. D., D. T. Walters, K. G. Cassman, and J. L. Lindquist. 2005. Nitrogen supply affects root:shoot ratio in corn and velvetleaf (Abutilon theophrasti). Weed Sci. 53:670-675.

Burger, M. and L. E. Jackson. 2003. Microbial immobilization of ammonium and nitrate in relation to ammonification and nitrification rates in organic and conventional cropping systems. Soil Biol. and Biochem. 35:29-36.

Davis, A. S. and M. Liebman. 2001. Nitrogen source influences wild mustard growth and competitive effect on sweet corn. Weed Sci. 49:558-566.

DiTomaso, J. M. 1995. Approaches for improving crop competitiveness through the manipulation of fertilization strategies. Weed Sci. 43:491-497.

Dyck, E., M. Liebman, and M. S. Erich. 1995. Crop-weed interference as influenced by a leguminous or synthetic fertilizer nitrogen source: I. Doublecropping experiments with crimson clover, sweet corn, and lambsquarters. Agric. Ecosyst. Environ. 56:93-108.

Harbur, M. M. and M.D.K. Owen. 2004a. Light and growth rate effects on crop and weed responses to nitrogen. Weed Sci. 52:578-583.

Harbur, M. M. and M.D.K. Owen. 2004b. Response of three annual weeds to corn population density and nitrogen fertilization timing. Weed Sci. 52:845-853.

Holm, R. E. and M. R. Miller. 1972. Weed seed germination responses to chemical and physical treatments. Weed Sci. 20:150-153.

[ISU] Iowa State University Cooperative Extension Service. 1993. How a Corn Plant Develops. Special Rep. No. 48.

Klapwyk, J. H. and Q. M. Ketterings. 2006. Soil tests for predicting corn response to nitrogen fertilizer in New York. Agron. J. 98:675-681.

Laboski, C.A.M., J. E. Sawyer, D. T. Walters, L. G. Bundy, R. G. Hoeft, G. W. Randall, and T. W. Andraski. 2008. Evaluation of the Illinois soil nitrogen test in the North Central region of the United States. Agron. J. 100:1070-1076.

Lawrence, J. R., Q. M. Ketterings, M. G. Goler, J. H. Cherney, W. J. Cox, and K. J. Czymmek. 2009. Illinois soil nitrogen test with organic matter correction for predicting nitrogen responsiveness of corn in rotation. Soil Sci. Soc. Am. J. 73:303-311.

Lindquist, J. L., D. A. Mortensen, S. A. Clay, R. Schmenk, J. J. Kells, K. Howatt, and P. Westra. 1996. Stability of corn (Zea mays)-velvetleaf (Abutilon theophrasti) relationships. Weed Sci. 44:309-313.

Lindquist, J. L., D. A. Mortensen, and P. Westra, et al. 1999. Stability of corn (Zea mays)-foxtail (Setaria spp.) interference relationships. Weed Sci. 47:195-200.

Lord, E. I. and R.D.J. Mitchell. 1998. Effect of nitrogen inputs to cereals on nitrate leaching from sandy soils. Soil Use Manag. 17:78-83.

Mary, B., S. Recous, D. Darwis, and D. Robin. 1996. Interactions between decomposition of plant residues and nitrogen cycling in soil. Plant Soil 181:71-82.

Menalled, F. D., M. Liebman, and D. D. Buhler. 2004. Impact of composted swine manure and tillage on common waterhemp (Amaranthus rudis) competition with soybean. Weed Sci. 52:605-613.

Mulvaney, R. L., S. A. Khan, and T. R. Ellsworth. 2006. Need for a soil-based approach in managing nitrogen fertilizers for profitable corn production. Soil Sci. Soc. Am. J. 70:172-182.

Mulvaney, R. L., S. A. Khan, R. G. Hoeft, and H. M. Brown. 2001. A soil organic nitrogen fraction that reduces the need for nitrogen fertilization. Soil Sci. Soc. Am. J. 65:1164-1172.

Osterhaus, J. T., L. G. Bundy, and T. W. Andraski. 2008. Evaluation of the Illinois soil nitrogen test for predicting corn nitrogen needs. Soil Sci. Soc. Am. J. 72:143-150.

Rasmussen, K. 2002. Influence of liquid manure application method on weed control in spring cereals. Weed Res. 42:287-298.

Seibert, A. C. and R. B. Pearce. 1993. Growth analysis of weed and crop species with reference to seed weight. Weed Sci. 41:52-56.

Shapiro, C. A., R. B. Ferguson, G. W. Hergert, C. S. Wortmann, and D. T. Walters. 2008. Fertilizer Suggestions for Corn. Lincoln, NE: University of Nebraska-Lincoln Extension Publication EC 117.

Shipley, B. and P. A. Keddy. 1988. The relationship between relative growth rate and sensitivity to nutrient stress in twenty-eight species of emergent macrophytes. J. Ecol. 76:1101-1110.

Spitters, C.J.T. 1983. An alternative approach to the analysis of mixed cropping experiments. 1. Estimation of competition effects. Neth. J. Agric. Sci. 31:1-11.

Stanford, G. and S. J. Smith. 1972. Nitrogen mineralization potential of soils. Soil Sci. Soc. Am. J. 36:465-472.

Williams, J. D., C. R. Crozier, J. G. White, R. W. Heiniger, R. P. Sripada, and D. A. Crouse. 2007. Illinois soil nitrogen test predicts southeastern U.S. corn economic optimum nitrogen rates. Soil Sci. Soc. Am. J. 71:735-744.

Received June 8, 2010, and approved October 16, 2010. 